\title{
Fresh water Algae of district Peshawar, Khyber Pakhtunkhwa, Pakistan
}

\author{
Tabassum Yaseen ${ }^{1 *}$, Muhammad Ali ${ }^{1}$, Fazli Malik Sarim ${ }^{1}$, Fazli Rahim ${ }^{1}$, \\ Sher Wali ${ }^{2}$ and Izhar Ahmad ${ }^{2}$ \\ 1. Department of Botany, Bacha Khan University, Charsadda, Khyber Pakhtunkhwa-Pakistan \\ 2. Departments of Botany, Islamia College, Peshawar, Khyber Pakhtunkhwa-Pakistan \\ *Corresponding author's email: sciences111@yahoo.com \\ Citation \\ Tabassum Yaseen, Muhammad Ali, Fazli Malik Sarim, Fazli Rahim, Sher Wali and Izhar Ahmad. Fresh water \\ Algae of district Peshawar, Khyber Pakhtunkhwa, Pakistan. Pure and Applied Biology. Vol. 5, Issue 4, pp927-933. \\ http://dx.doi.org/10.19045/bspab.2016.50117
}

Received: 27/04/2016

Revised: 04/08/2016

Accepted: 10/08/2016

Online First: 23/08/2016

\section{Abstract}

Algae are simplest and chlorophyll bearing organism and not differentiated into true leaves, stems and roots. Algae habitat is fresh water. Algae have pivotal role on earth. They are primary producers and form strong food chains mostly in aquatic environment. It constitute important group, so it was desired to work out the freshwater algae of District Peshawar. In the research area total of 13 genera with 51 species of algae found in District Peshawar which belong to Chlorophyta (64\%), Cyanophyta (18\%), Xanthophyta (2\%), Charophyta $6 \%$ and Chrysophyta $(10 \%)$ were identified and properly key referenced. The frequent genus in term of species was Spirogyra with 11 species (22\%), Oscillatoria with 9 species (18\%), Chara, Zygnema and Nitzschia have 3 species each $6 \%$, Cladophora with 7 species (14\%), Closterium with 5 specie (10\%), Ulotehrix with 4 species (8\%), Rhizoclonium with 2 species (4\%), Vachoria, Mougeotia, Ophiocytium and Dinobryon have $1 \mathrm{spp}$. (2\%). The present study will help to know the ecological distribution of fresh water algae in Peshawar.

Keywords: Chlorophyceae; Charophyceae; Cyanophyceae; Chrysophyceae; Xanthophyceae

\section{Introduction}

Peshawar surrounded by (Charsadda, Nowshera, Mardan, Swabi and parts of Malakand, Mohamand and Khyber Agencies). Peshawar about $(8800 \mathrm{Km})$. It lies between (710 15/ and 720 47/) East longitudes and (330 40/) and (340 31/) North latitudes. A lot of algae belong to fresh water inhibited in aquatic form and form a diverse group mostly belong to Cyanobacteria form a thick and heavy blooms. The toxic substances which are produced by them may not contain so high concentrations likely to become harmful to human being and livestock. But even in some cases 'fresh water or brackish water' having one or more spp. of algae. These type of algae form a huge group of algae and they are grouped according to their size and ranged (one micrometer to several. Algae form a huge food chain mostly in lakes. In fresh water algae produced toxin substances which are harmful for aquatic organisms [1]. Peshawar is a 'semiarid climate' with extreme summer and winter seasons. Winters from (November-March). The mean 'maximum temperature in summer is over $40{ }^{\circ} \mathrm{C}$ ' and the mean 'minimum summer temperature is $25^{\circ} \mathrm{C}$ '. The mean 'minimum temperature during winter is $4^{\circ} \mathrm{C}$ ' 
and 'maximum may be upto $18{ }^{\circ} \mathrm{C}$ '. Many worker have investigated and extracted algae from fresh water bodies and aquatic area of Pakistan to know the ecological distribution [2-4]. Algae are very important photosynthetic organisms on this earth. Aquatic web foods are formed due to algae which help and support animals. Pakistani phycologist find out fresh water algae from different area of Pakistan [3, 5-7]. The present report is further contribution to the algal flora of Peshawar that will help others to know the ecological distribution of different flora of fresh water algae

\section{Materials and methods}

The fresh algae samples were collected from District Peshawar. These samples were collected from different areas of Peshawar five sites were selected for collection of samples. These were Gulbahar, Ring Road Jamel Chock, Pando Payan, Zandai Camp and Hazara Khwani. The samples were collected in different duration of the year from February 2014 to January 2015. These samples were collected from running water, shallow water and standing water. These samples were also collected from the bottom of the stream and also from aquatic plants. These samples were collected with the help of knife and stick in polythene bag. The samples were brought to the laboratory of Bacha Khan University Charsdda in polythene bags. The samples were preserved in $4 \%$ formalin in the glass bottles. Slides were prepared and checked with the help of light microscope by different magnification. And Identified [8, 9].

\section{Results and discussion}

In present study 51 species belonging to 13 genera and 5 classes were identified from different fresh water habitats of Gulbahar areas. Major class were found to be Chlorophyceae (33 spp) and Class Charophyceae (3 spp) previously this classes reported by [10] who reported 33 species of Chlorophyta from Peshawar Valley. 41 species of Chlorophyta were listed from Peshawar Valley [11]. The result was strongly supported by [12] studied Fortytwo from different fresh water areas of 'Gujranwala, Jhang, Kasur, Lahore, Sheikhupura, Sialkot and Attock Districts of the Punjab Province and Swat' of KPK. Our results agree with the findings of [13-16] from India and [11, 17-19]. Class Cyanophyceae (9 spp) previously this class investigated by [20]. 30 species of Cyanophyta and our results corelated with the statement that Cyanophyta was the pre dominant in polluted areas. Class Chrsophyceae (3 spp) previously this class reported by [21] reported Chrysophyta from fresh water riverian ponds. Same investigation related with our results. Class Xanthophyceae (1 spp) previously this class reported $[1,22]$.

\section{A. Class Cyanophyceae}

Key to Species: Oscillatoria

1. Apical cell with a flattened calyptras cell

2.5-5 $\mu$ in diameter $O$. prolifica

2. Cells with distinctly granular cross walls3

3. Cells with rows of granules at the cross walls $O$. tenuis

4. Trichomes which are $7.4-10 \mu$ in diameter

O. tenuis var natan

5. Proportions 5.5-6 $\mu$ in diameter O. tenuis var. tergestina.

6. Cells almost colorless, with large, conspicuous alveoli or vacuoles $O$. Bornetii

7. Trichomes hooked at the apex $O$. curviceps

8. Trichomes bent or hooked at the apex cells $7-8 \mu$ in diameter forming a plant mass $O$. anguina

9. Cells not granular at the cross walls $O$. subbrevis

10. Constricted at the cross walls $O$. chalybea. 

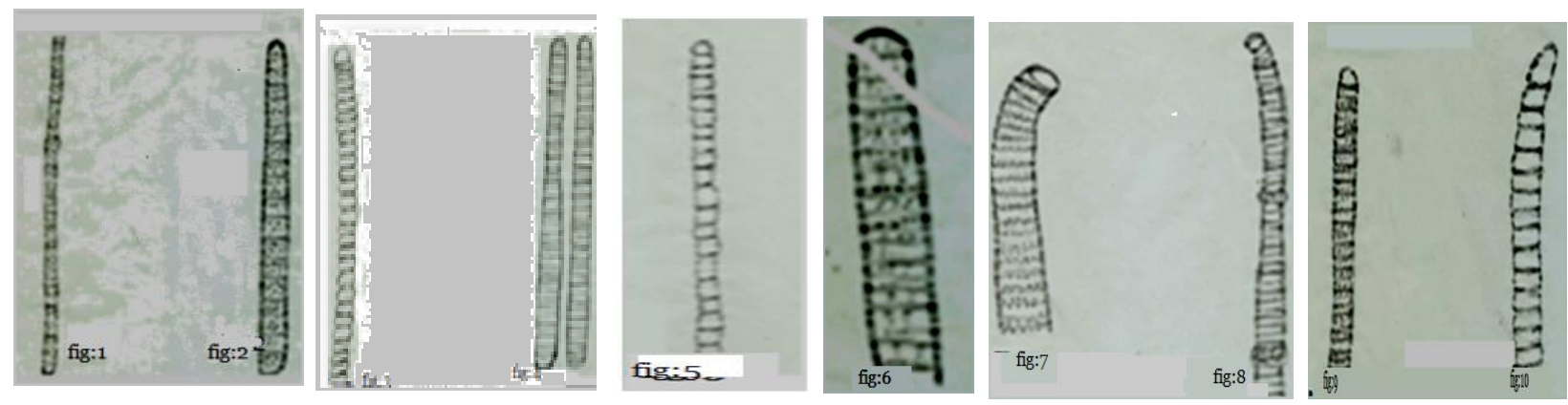

Figure 1, 2. Oscillatoria prolific, Figure 3. Oscillatoria tenuis, Figure 4, Oscillatoria tenuis var natan, Figure 5. Oscillatoria tenuis var targestina, Figure 6. Oscillatoria broneti, Figure 7. Oscillatoria curviceps, Figure 8. Oscillatoria anguina, Figure 9. Oscillatoria subbrevis, Figure 10. Oscillatoria chalybea

\section{B. Class Chlorophyceae}

Key to species: Spirogyra

11 \& 12. Zygospores averagig larger, 38-62 in dimatter spore wall irregularly reticulate filament of rather stout cell $40-59 \mu$ in diameter $S$. rhizobrachialis

13. Vegetative cells $23-25 \mu$ in diameter $S$. aequinoctialis

14. Vegetative cells 40 to44 in diameter up to 240 long Chloroplast 3, making 1-2 turns spores 32 to in diameter $S$. fuellebornei

15. Ovate median spore wall pitted $S$. crassa 16. Spore ellipsoid, $35-44 \mathrm{~m}$ in diameter $S$. daedaleoides
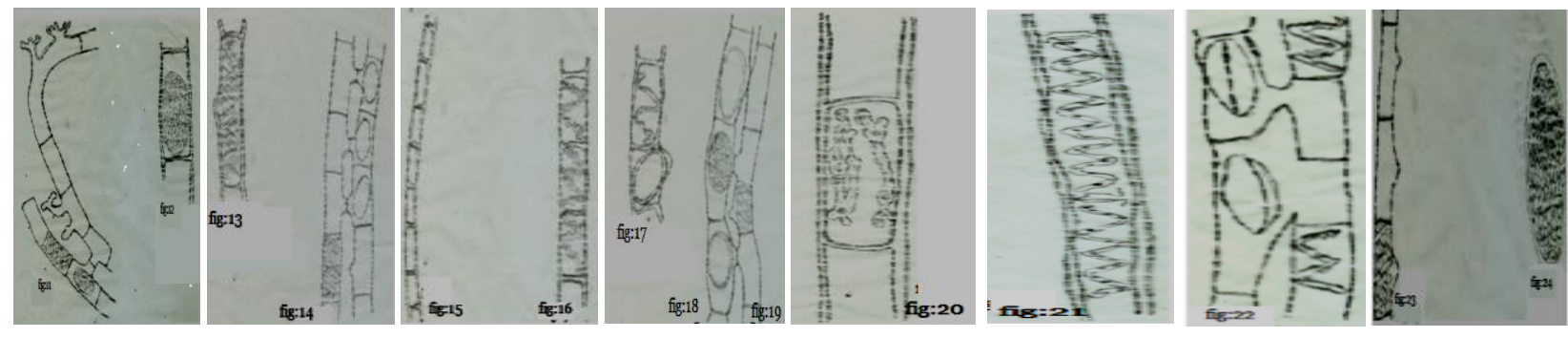

Figure 11, 12. Spirogyra rhizobrachialis, Spirogyra condensate, Figure 13. Spirogyra aeqinoctialis, Figure 14. Spirogyra fullebornei, Figure 15. Spirogyra crassa, Figure 16. Spirogyra daedaleoides, Figure 17. Spirogyra condensa, Figure 18, 19. Spirogyra fluviatilis, Figure 20. Spirogyra psodoflorodina, Figure 21. Spirogyra weberii, Figure 22. Spirogyra circuminata, Figure 23, 24. Spirogyra novae angliae 


\section{Class Charophyceae}

Key to Species: Chara

25. Longer than the mature fruit $C$.

Schiveinitzii

$26 \& 27$. Lateral cortical cell in pairs and more prominent than the primary cell; posterior bacts much shorter than the Oogonium C. vulgaris

28. Cortication C. canescens

Key to Species: Cladophora

29. Vegetative cells $60-120 \mu$ in diameter $C$. fracta
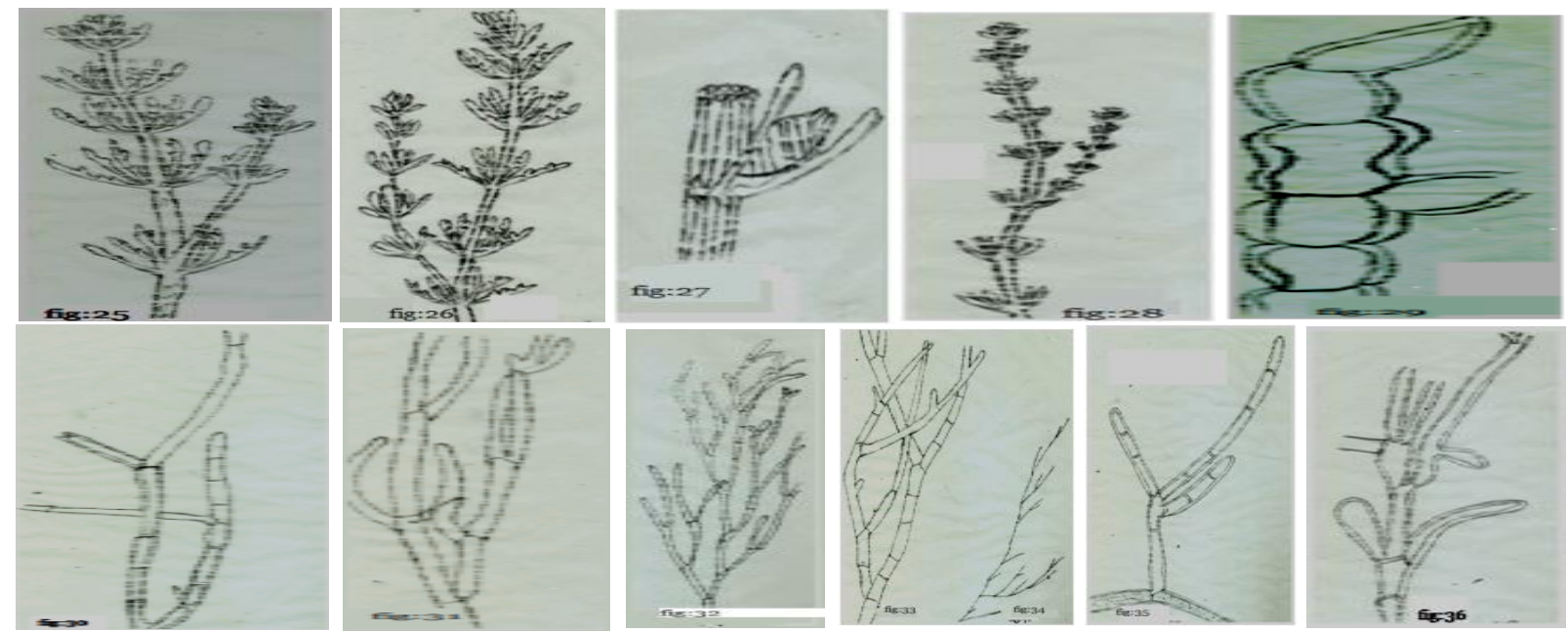

Figure 25. Chara schweintzii, Figure 26 \& 27. Chara vulgaris, Figure 28. Chara canescens, Figure. 29. Cladophora fracta, Figure. 30. Cladophora fracta var lacutris, Figure 31. Cladophora oligoclona, Figure 32. Cladophora glomerata, Figure 33 \& 34. Cladophora crispate, Figure 35. Cladophora insigins, Figure 36. Cladophora profunda

\section{Class Xanthophyceae}

Key to Species: Vaucheria

37. Oogonia 60-103 $\mu$ in diameter, $85-211 \mu$ long without pedicle from the branch, arising near the base of the antheridia $V$. terrestris

Key to species: Mougeotia

38. Vegetative cell $25-33 \mu$ in diameter $M$. robusta

Key to species: Zygonema

39. Vegetative cell 17-21 $\mu$ in diameter,zoospores in the tube formed Zygonema synadelphum
40. Filment form light green vegetative cells $30-40 \mu$ diameter up to $80 \mu$ long median spore wall Zygonema pectinutum

41. Vegetative cell $18-20 \mu$ in diameter up to $100 \mu$ long,zoospores in tube,median spore wall brown Zygnema decussate

Key to Species: Ulothrix

42. Filaments $20 \mu$ or more in diameter, wall thick $U$. zonata

43. Cells $13-16 \mathrm{~m}$ in diameter, 1-2 times longer than wide $U$. aequalis

44. Cells up to $20 \mu$ in diameter, shorter than wide $U$. tenuissima 
45. Cells larger, 6-9 $\mu$ in diameter $U$. variabilis

Key to Species: Rhizoclonium

46. Filament, freely bunching, crisp, cylindrical, inflantted cells, 60-64 $\mu$ in diameter and 7 times their diameter in length Rhizoclonium hookeri

47. Filament coarse, cell cylindrical but uneven lateral walls and 1.5-2 $\mu$ thick, and up to $80 \mu$ long Rhizoclonium fontanum

E. Class Chrsophyceae

Key to Species: Dinobryon

48. Swellings at the base of the anterior portion D. sertularia

Key to Species: Ophiocytum

$49 \& 50$. Cell smallest, (2.7)-5-10 $\mu$ in diameter; spines shortest and sharp $O$. capitatum
Key to Species: Nitzschia

51. Valves 5-7 $\mu$ broad $N$. palea

52. Valves linear, 70-180 $\mu$ long $N$. linearis

53. Valves margin undulate Nitzschia sinuata var. tabellaria

Key to Species: Closterium

1. Inner margin straight or straightly convex 1

54. Apices acutely rounded $C$. lanceolatum

55. Apices rounded- truncate $C$. acersum

56. Cells gradually covered from middle to pole $C$. acutum

57. Striation not composed of punctae $C$. turgidum

58. Chromatophore with 1-2 pyrenoids $C$. venus

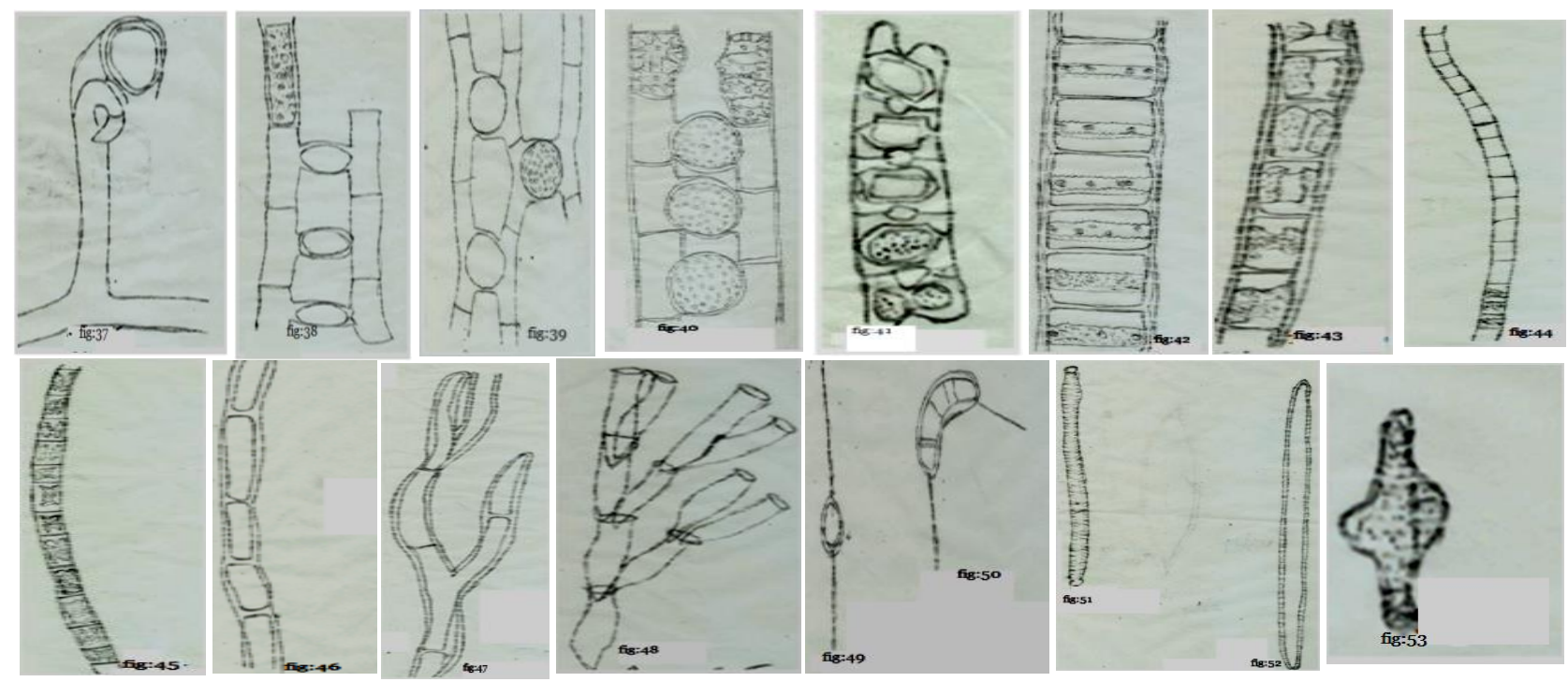

Figure 37. Vaucheria terrestris, Figure 38. Mougeotia robusta, Figure 39. Zygonema synadelphum, Figure 40. Zygonema pectinutum, Figure 41. Zygnema decussate, Figure 42. Ulothrix zonata, Figure 43. Ulothrix aequlis, Figure 44. Ulothrix tenuissima, Figure 45. Ulothrix variabilis, Figure 46. Rhizoclonium hookeri, Figure 47. Rhizoclonium fontanum, Figure 48. Dinobryon sertularia, Figure 49 \& 50. Ophiocytum capitatum, Figure 51. Nitzchia palea Figure 52. Nitzchia linearis Figure 53. Nitzschia sinuata var. tabellaria 


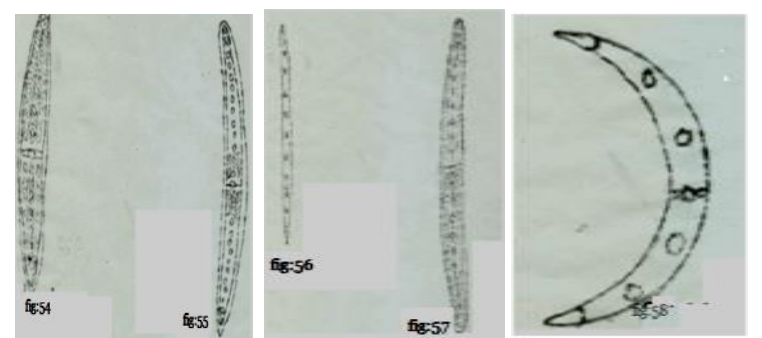

Figure 54. Closterium lanceolatum, Figure 55. Closterium acerosum, Figure 56. Closterium acutum Figure 57. Closterium turgidum Figure 58. Closterium venus

\section{Conclusion}

Algae in fresh waters have numerous environmental functions and are based upon the recycling of nutrients. Urbanization has led to the pollution of surface water bodies resulting in decline/extinction of some species. On the other hand, some species have increased enormously making water unfit for drinking and recreation. This study only comprises the taxonomic position of algae. It is proposed that a combined i.e. taxonomical and limno logical study should be done to understand the biodiversity of alga in fresh water bodies of District Peshawar, Khyber Pakhtunkhwa, Pakistan

\section{Authors' contribution}

Conceived and designed the experiments: T Yaseen, M Ali \& FM Sarim, Performed the experiments: M Ali, Analyzed the data: M Ali, FM Sarim \& T Yaseen Contributed reagents/materials/analysis tools: $\mathrm{F}$ Rahim, S Wali \& I Ahmad, Wrote the paper: $\mathrm{T}$ Yaseen \& M Ali.

\section{References}

1. Bellinger EG \& Sigee DC (2010). Freshwater algae identification and use as bioindicators. John Wiley \& Sons, Ltd, The Atrium, Southern Gate, Chichester, West Sussex, PO19 8SQ, UK. pp 271.

2. Khalid MN, Mustafa S \& Saleem S (2010). Studies on bioactivities and phycochemistry of Microcystis aeruginosa (Cynophycota) from Sindh. Pak J Bot 42: 2635-2646.

3. Lashari $\mathrm{KH}$, Korai AL \& Sahato GA (2009). Biodiversity of Oscillatoria (Nostophyceae, Cyanophyta) from Lakes and Ponds of Sindh. Res. Journal. Fishes and Hyd 4: 73-85.

4. Ungsethaphand $\mathrm{T}$, Peerapornpisal $\mathrm{Y} \&$ Whangchai N (2009). Production of Spirulina platensis using dry chicken manure supplemented with urea and sodium bicarbonate. Maejo international journal of science and technology 3: 379387.

5. Anjum G \& Hussain F (1984). Two new algae from Peshawar valley. Pak J Bot 16 (1): $85-86$.

6. Ali ST, Hasan MU \& Shameel M (2008). Occurrence of the families Naviculaceae and Surirellaceae (Bacillariophyta) in the Punjab and N.W. F. P. Pakistan. Pak J B 40(5): 2143-2148.

7. Sarim FM (2005). The fresh water algae of Bara River Peshawar, Pakistan. Pak J Pl Sci 11(1): 133-136.

8. Prescott GW (1941). Algae of western great lake area, Cranbrook. Inst. Bloomfield hills, Michigan. U.S.A. pp. 946.

9. Tiffany LH \& Britton ME (1952). The Algae of Illinois. Chicago. Univ. Press. U.S.A. pp. 406.

10. Nawaz A \& Sarim FM (2004). The freshwater algae of Swat River. Putaj 10: 181- 183.

11. Zaman A, Hussain F \& Sarim FM (2009). Genus Spirogyra from Peshawar Valley, Pakistan, Pak J Pl Sci 15(2): 115122.

12. Asghar A, Shinwari ZK \& Sarim FM (2010). Contribution to the algal flora (chlorophyta) of fresh waters of district swat. N.W.F.P., Pakistan. Pak J Bot 42(5): 3457-3462. 
13. Ara J \& Faridi MAF (1978). The genus Spirogyra of Peshawar Valley. Biologia 24: 421-436.

14. Misra PK, Srivastava AK, Prakash J, Asthana DK \& Rai SK (2005). Some fresh water algae of eastern Uttar Pradesh, India Our Nature 3: 77-80.

15. Shankar \& Hosmani H (2004). Biodiversity of fresh water Algal Blooms. Biodiversity and Environment 17-27.

16. Reshmi S (2004). Chlorophycean biodiversity in Wet lands of Satna (M.P.) India. Biodiversity and Environment 171-190.

17. John DM, Whitton BA \& Brook AJ (Eds.) (2002). The freshwater algal flora of the British Isles: An identification guide to freshwater and terrestrial algae. Cambridge University Press.

18. Janjua NS \& Ejaz N (2009). Solid waste management issues in small towns of developing world: a case study of Taxilacity. International Journal of
Environmental Science and Development 3(2): 167- 171.

19. Sarim FM, Ahmad I, Ali N \& Zaman A (2010). Cyanophyceae of District Charsada, Pakistan. Pakistan journals of plant sciences 16: 91-98.

20. Sarim FM \& Zaman A (2005). Some freshwater algae of District Charsadda NWFP, Pakistan. Peshawar University Teacher's Association Journal (PUTAJ) 12: 5-10.

21. Leghari SM (2001). Some fresh water Green Filamentous Algae (Chlorophyta) and Dinobryon cylindricum (Chrysophyta) from Lakes and Riverin Ponds of Sindh, PaK Online $J$ Biological Sci 1(3): 145-149.

22. Tedesco S, Barroso TM \& Olabi AG (2013). Optimization of mechanical pretreatment of Laminariaceae spp. biomass-derived biogas. Renewable and Sustainable Energy Reviews 27: 596604. 